Оливера М. Дурбаба*

Универзитет у Београду**

Филолошки факултет
811.163.41'374.2'276.2

doi 10.18485/analiff.2015.27.2.11

\title{
О НЕСТАНДАРДНОЈ ЛЕКСИЦИ У ЛЕКСИКОГРАФСКИМ ИЗВОРИМА
}

У раду су приказане терминолошке дефиниције појмова који се односе на нестандардну лексику (колоквијализме, жаргонизме, арготизме, елементе сленга и шатровачки говор, пејоративе, вулгаризме, интензификаторе, фамилијаризме, елементе урбане лексике, помодне англицизме, фејзбукизме итд.) у неким најважнијим речницима српског језика - Речнику Маииице срйске, Речнику сиираних речи и израза Милана Вујаклије, Великом речнику сиираних речи и израза Ивана Клајна и Милана Шипке, као и у Речнику књижевних иеррмина. Анализа дефиниција ових појмова показује да међу њима не постоји прецизно терминолошко разграничење.

Кључне речи: нестандардна лексика, лексикографски извори, колоквијализми, жаргон, жаргонизација

Лингвистичка литература не пружа увек сасвим прецизне дефиниције појмова везаних за нестандардну употребу језика (овде превасходно мислимо на колоквијализме, жаргонизме, арготизме, елементе сленга и шатровачки говор), које би омогућиле потпуно јасно разграничење ових лексички маркираних елемената, стилских поступака и техника (попут колоквијализације или жаргонизације). Сличан недостатак се може констатовати и увидом у лексикографске изворе, што ћемо овде илустровати подацима забележеним у Речнику сиираних речи и израза Милана Вујаклије (обележено сиглом МВ), Речнику къижевних йермина (РКТ), Речнику Майице срйске (РМС) и Великом речнику сйраних речи и израза Ивана Клајна и Милана Шипке (К\&Ш).

*_olja.durbaba@fil.bg.ac.rs, oljadurbaba@yahoo.de.

** Овај рад израђен је у оквиру пројекта Динамика структура српског језика, 178014, који финансира Министарство просвете, науке и технолошког развоја Републике Србије. 1 
Према лексикографском објашњењу датом у МВ термином колоквијализам се назива ,реч (или израз) својсиивена разіооворном језику (нйр. ,, Ужасно сам се уморио; Сйрашно ми ї је жао: и сл.)“. У РКТ се такође наглашава да је у питању „(и)зраз или облик који се каракииеристиично јавља у свакояневном разіоворном језику, али се махом избеїава

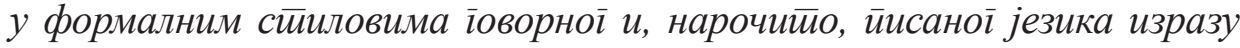
или облику из свакояневної разїоворноі језика“, уз даљу констатацију да се овакве појаве избегавају у формалном стилу (говорном, а поготову писаном). За примере се наводе кола или ауйо (ауйомобил), банка $(\text { gесей gинара) })^{1}$, ирьак (ирно вино). Овде се, такође, захтева прављење (строге!) разлике између колоквијализма, с једне, као и жаргона и аргоа, с друге стране „тим пре што је пуризам допринео неоправданом и ненаучном мешању ових категорија“. К\&Ш и РМС не наводе ову одредницу, при чему се у РМС појављује објашњење за колоквијалан: „који се оgноси на разіоворни језик, својстивен разїоворном језику“, и за пример употребе наводи колоквијалан йон.

Дефинисање појма жаріон такође није сасвим једноставан поступак, као што то примећује и један од најпреданијих истраживача овог феномена у нашој лингвистици, Ранко Бугарски, утврдивши да се овај израз употребљава у различитим значењима, ширег и ужег спектра, али да је свима њима заједнички именитељ да се жаргон користи у циљу групне идентификације, односно одвијања комуникације у оквиру друштвено дертерминисане групе (Бугарски 2006: 12).

Лексикографски извори потврђују основне лингвистичке констатације (в. Бугарски 2006: 23 и даље) - жаргонизми јесу категорија настала путем социјално условљеног језичког раслојавања, што их сврстава у социолекте; јављају се у употреби припадника јасно издвојених друштвених група (било професионалне провенијенције било групе која се издваја по критеријуму релативне друштвене компактности и диференцираности у односу на друге групе; у овом контексту Бугарски наводи да чланове групе повезане професијом, социјалим статусом, узрастом издваја заједнички интерес, начин живота, територијална омеђеност). У свим лексикографским изворима који су овде консултовани наглашава се да жаргон обухвата специфичне речи и изразе, који су изван групе у којој се користе „мање

1 О примеру облика банка више у Прилогу I. 
разумљив(и) за gруїе, арі̄o“ (РМС), односно непознати (К\&Ш); у РКТ се такође потенцира да је жаргон ,разумљив (...) само онима који ирийagajy gоиичном стиалежу, ирофесији, іруйи“. Сви извори ову одредницу додатно вредносно квалификују као нестандардну употребу језика, и то као „некњижевни локални іовор, шайровачки іовор; Ђачки жаріонн (РМС), односно „,(ш)аирровачки іовор, арїо, сленї“ (К\&Ш), „(ü)окварен (или: неразумљиив, йоірешан) іовор“ (В), „(и)скварен, неиравилан и неразумљив іовор“"(РКТ). У овом потоњем извору као примери се наводе војнички, грађански, морнарски и спортски жаргон и истиче да жаргон има делимично пејоративан смисао, те да се по томе разликује од аргоа.

У овом истом извору се веома опсежно описује и сама одредница apīo, почев од историјата њеног настанка у XIII веку (документовано најпре у немачким изворима; одговарајући немачки пандан француском аргоу јесте Rotwelsch), преко употребе у баладама Франсоа Вијона у XV веку, са првобитним значењем ,удружење скитница и пробисвета“", које је током времена (XVII-XIX век) проширено на говор просјака, лопова и свих других друштвених маргиналаца. Истиче се још и да је језик остао тајновит због друштвене изолованости његових корисника, све док у XIX веку није почео да продире и у књижевност (нпр. у делима Игоа и Балзака). Према РКТ у данашње време то више није облик вулгарног језика већ се њиме користе и одређене

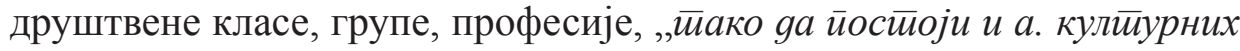
слојева ярушишв: уметиника, ученика, сииуденайа“. У овом значењу РКТ упућује на жаріон и слені. У овом извору наводи се још и начин настанка аргоа - речи се изобличавају одузмањем слогова, додавањем префикса и суфикса и мењањем њихових значења. Интересантно је приметити да се у РКТ код одредница жаргон и арго појављују две супротстављене тврдње: премда се, наиме, за жаргон констатује да, за разлику од аргоа, има и пејоративно значење, и уз одредницу арго јасно се тврди да, макар у историјском смислу, он јесте (био) обележје маргиналних група, „некултурних“ слојева друштва и уз то још вулгарног карактера, што такође сугерише његову негативну карактеризацију.

У К\&Ш и РМС се одредница арго идентификује са шатровачким говором, жаргоном и сленгом без навођења икакве differentia specifica између ових термина. У РМС се још констатује да је то језик одређене друштвене групе, професије, заната, који је за друге неразумљив, 
а за примере се наводе зидарски, војнички, студентски и рибарски арго. Коначно, у МВ је арго ,језик йариске улице и йолусвейа; лойовски, маніуйски, шайровачки іовор; їовор љуяи јеgне класе или јеgної занайа“; оваквом дефиницијом такође се истиче повезаност ове нестандардне језичке праксе с маргиналним социјалним групама и њена обавезујућа тајанственост.

Што се тиче термина слені, у два извора се не повлачи јасна линија разграничења у односу на арго, жаргон или шатровачки говор²; заузврат, оба речника страних речи под овим подразумевају посебан говор неке групе људи (МВ), односно затворене групе, скупине људи (К\&Ш). У МВ се још наводе примери - спортски, рибарски, студентски, војнички, ловачки, глумачки, шатровачки - и указује на порекло сленга и његову стилску вредност (,вулїарне речи и изрази лондонске улище“). И у К\&Ш се као синоними наводе облици жаргон и арго, а истиче се и стилска маркираност сленга (,,іоворни ияиом нижеї рані̄a

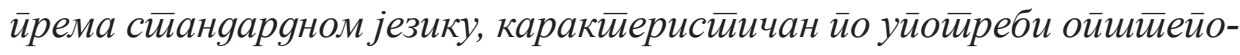
знайих речи у ирренесеном значењу"). Интересантно је да се управо овај последњи принцип - употреба општепознатих речи у пренесеном значењу - који се у К\&Ш издваја као карактеристика сленга, код Бугарског (2006: 22) јавља као први у низу од десетак модела жарго-

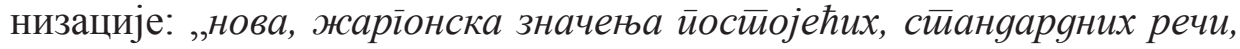
честио изведена метиафоризацијом“".

У РКТ се уз одредницу шайровачки іовор само упућује на арго, у К\&Ш се за шатровачки говор тј. шатровачки језик наводи да је то

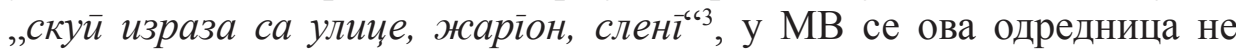
појављује, док се у РМС даје најопсежнија дефиниција два могућа значења: 1. специфични говор, речи и изрази којим се служе шатровци ${ }^{4}$, мангупи, скитнице; специфични афективни начин изражавања уобичајен међу омладином; жаргон, сленг уопште. 2. говор лончара, зидара и неких др. занатлија, арго.

Ако све наведене дефиниције овде анализираних појмова преточимо у неколико основних сема, тј. значењских компоненти (појављи-

$2 \mathrm{PMC}=$ арго, жаргон, патровачки однос; РКТ $=$ (енгл. slang - шатровачки говор) $\rightarrow$ арго.

$3 \mathrm{У}$ К\&Ш се дефинише и појам шатровац, и то као: „1. скитница, бескућник, чергар; 2. онај који живи од крађе и просјачењаа, ситан лопов.“

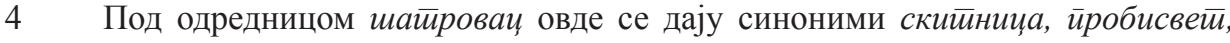
манйуи; сийан лойов, цейарош. 
вање у разговорном језику; некњижевна, искварена, вулгарна употреба језика; језичко обележје одређене социјалне групације; језичко обележје маргиналних група; неразумљивост изван дате социјалне групације), можемо табеларним приказом утврдити да је, са изузетком колоквијализама, код свих осталих (жаргон, арго, сленг и шатровачки говор) потврђено постојање свих наведених сема. Ово намеће закључак да, као што је на основу сличне анализе из РМС и РСАНУ приметио Бугарски (2006: 23-24), лексикографски описи нису довољно прецизни и информативни за дубља лингвистичка истраживања.

\begin{tabular}{|l|c|c|c|c|c|}
\hline & $\begin{array}{c}\text { у разговорном } \\
\text { језику }\end{array}$ & $\begin{array}{c}\text { некњижевна, } \\
\text { искварена, } \\
\text { вулгарна } \\
\text { употреба } \\
\text { језика }\end{array}$ & $\begin{array}{c}\text { обележје } \\
\text { одређене } \\
\text { социјалне } \\
\text { групације }\end{array}$ & $\begin{array}{c}\text { обележје } \\
\text { маргиналних } \\
\text { група }\end{array}$ & $\begin{array}{c}\text { неразумљиво изван } \\
\text { дате социјалне } \\
\text { групације }\end{array}$ \\
\hline колоквијализам & + & + & & + & + \\
\hline жаргон & + & + & + & + & + \\
\hline арго & + & + & + & + & $(+)$ \\
\hline сленг & + & + & + & $(+)^{1}$ & $(+)$ \\
\hline шатровачки & + & $(+)$ & + & + & + \\
\hline
\end{tabular}

Недостатак дистинктивних значењских обележја између ових термина ипак не значи да су сви заиста идентичног поља употребе. Чини се, наиме, да једино облик жаріон може покрити све сфере значења у свакодневном језику, па и у лингвистичким проучавањима. За разлику од њега, појмови шайровачкої їовора и арїоа већ су у свом првобитном значењу делимично превазиђени. Код овог првог - шатровачког - акценат је на искварености говора као и на специфичним начинима творбе путем пермутације (лий $а, \bar{u} е б р а ~=\bar{u} а л и, ~ б р а \bar{u} е)^{5}$ или итерације слогова, док је овај потоњи, арго, по свом пореклу био везан превасходно за социјално депривилеговане слојеве, и у овом и у каснијем ширем значењу потискиван новијом (и модернијом) позајмљеницом сленг (без изразитије разлике у значењу између ова два термина). И ранија позајмљеница из француског (арго) и новија из енглеског (сленг) првобитно су (пре више векова) означавале тајних говорне карактеристике маргинализованих, кримогених група (оних

5 Као у слогану популарном међу млађом популацијом интернетских конзумената (и зависника?): „Ко нема у вуїлу (вуїла = їлава), ииражи у іууілу“. 
које у циљу опстанка имају потребу за тајновитошћу у односу на све друге социјалне групације). Примера ради, у Тошовић 1988: 114 истиче се да је арго представљају „,йајни језици лойова, наркомана, алкохоличара, швериера ийg.“. То основно значење је касније проширено на виши ниво општости - језик сваке мање-више посебне социјалне групације (која има потребу за формирањем и неговањем свог посебног комуникационог кода). Чињеница да је облик из француског језика замењен обликом преузетим из енглеског чини се утолико очекиванијом уколико је посматрамо и у контексту употребе речи сленг у значењу специфичног омладинског жаргона (нпр. у том смислу, најчешћи и у говору најуобичајенији јесу облици жаргон и сленг (жаргон и у смислу професионалног/стручног језика: лекарски жаріон, ИТ-жаріон). Међу најинтересантније и најкреативније појавне облике спадају они који се односе на говор младих (ђачки/ омладински/ студентски жаргон/ сленг $)^{6}:$ „Носиоци омладинског жаргона (...) имају и потребу да истакну своју самобитност, несврстаност, изузетност, отклон од стереотипа који припадају свету одраслих, што понекад подразумева и негацију других, несвојих, а то се све остварује кроз језичку игру“ (Милорадовић 2012: 25). У овом образложењу садржана су два битна елемента жаргона - потреба за потврђивањем групног идентитета (у случају омладинског жаргона у питању је освајање простора слободе у односу на одрасле путем сваковрсне па и језичке побуне) и разликовања од других путем оригиналности, креативности, језичке игре, акробатике и каламбура као уобичајених поступака настанка нових језичких елемената. У овом смислу у Милорадовић 2012:19 говори се о жаргону као истовременом средству унификације и диференцијације (идентификација са 'својима' и супротстављање 'туђима'). Осим тога, један од суштинских фактора младости чини и брзина реакције на животне догађаје па и на саму друштвену стварност, што такође погодује динамичном настајању омладинског жаргона. Ово се може илустровати чињеницом да у иначе врло опсежном прегледу који је Бугарски понудио пре свега десетак година (Бугарски 2006) не постоје (односни нису ни могли постојати, јер се односе на скорашње друштвене појаве)

6 Већ и сам увид у литературу коју су користили, рецимо, Бугарски 2006 и Милорадовић 2012 потврђује да је највећи број лингвистичких радова посвећен управо жаргону младих. 
неки у данашњем говору младих изузетно фреквентни облици као што су форумаш, сиилаваруша, комуналаи, блоиеерка/иренясешерка итд.). С друге стране, ове муњевите реакције стварања нове лексике условљавају и њен кратки животни век. Наиме, највећи број жаргонизама траје на друштвеној сцени таман толико док не одрасте генерација која их је створила, тако да би се у том контексту могло говорити о фосилизацији или потпуном ишчезавању жаргонизама ${ }^{7}$. Осим овог релативно кратког животног века, у главне карактеристике сленга убраја се, извесно, и његов експериментални карактер, в. Сорниг (Sornig) 1981: 19-20: What goes on in language development in general, viz. the acceptance of new and discarding of old words, is accelerated in slang development. Slang is, as it were, a language in statu nascendi (or at least a lexicon) in the making. Slang is essencially an experimental language.

Што се тиче осталих специфичних форми разговорног стила, у лексикографским изворима не налазимо потврду за све напред наведене. Најпрецизније су дефинисани иејорайиви, као речи и изрази с погрдним значењем; у МВ се још додаје: „образована йомоћу наро-

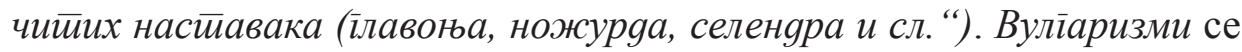
описују као просте, непристојне, грубе речи и изрази. Њих најчешће чини лексика која у денотативном смислу покрива домен сексуалности, људске анатомије и физиологије и има изразити експресивни капацитет (при чему ваља имати у виду да оне нису неминовно негативно конотиране, тј. да могу бити употребљене и као израз блискости, срдачности и сл.). Нарочити, а у усменом општењу и најфреквентнији тип вулгаризма представљају псовке. РМС за псовку наводи следеће: „нейрисииојна, йойрgна реч (или усйаљена іруйа речи) уйойребљена у љуйьи, іневу (или без разлоїа), која се обично уйућује некоме као увреga.“ Термин инииензификайори дефинише само МВ и то као „речи које означавају или наїлашавају снаїу или високу меру нечеі̄; нйр. йрилози сширашно, веома и сл." С обзиром да се овим типом лексике такође може вербализовати емоционални набој, он је чест у разговорном стилу; осим одређених адверба, попут оних који се наводе у МВ, али и неких колоквијалних (невиђено, ужасно, жешће...), у актуелном тренутку бележимо да се у функцији интензификатора у омладинском жаргону учестало користи деадјективски творбени модел с префиксом

7 Ово ћемо у додатку илустровати кратким екскурсом везаним за жаргонску употребу лексеме банка. 
„,ире“, и то у нестандардним комбинацијама с придевима који у основи већ изражавају висок степен одређене особине: ирејако, ирејебено, ирестирашно, иресмешно. Неретко се овако конструисан придев комбинује с неким додатним адвербијалним интензификатором (,gledam neki prejebeno strasan film“) или нефлектираним англицизмом („13 prekul fotografija sa savršenim tajmingom") Са овим префиксом су забележене и супстантивске конструкције, ев. додатно маркиране вулгаризмом (као у примеру йрейичка = изузейно зіоонна девојка ${ }^{8}$ ).

За фамилијаризме смо лексикографску потврду нашли само у

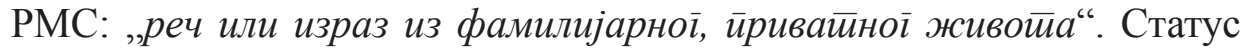
ове категорије је утолико проблематичан што фамилијаризми у ужем смислу (дакле, речи и изрази познати само у микросоцијалном окружењу, тј. у кругу уже или шире породице) не могу имати комуникациону вредност изван тог круга, будући да другим саговорницима нису познате; ипак, не може им се одрећи стилогена вредност, која се најчешће огледа у хумористичком ефекту или ефекту онеобичавања, премда може изазвати и неке друге реакције ${ }^{9}$. Фамилијаризми у ширем смислу могу се делимично преклапати и са нешто шире стратификованом лексиком (нпр. оном која карактерише урбанолекте или региолекте, као нарочите врсте функционалних варијетета), те тако ипак бити разумљиви већем броју учесника у комуникацији ${ }^{10}$. Под урбанолектима $^{11}$ и региолектима се подразумевају стратификовани појавни облици језика у употреби на географски ограниченом ареалу (града или шире регије); тако се нпр. може говорити о београдском,

8 Прва два примера са префиксом йре- преузета су са интернета, док је последњи пример добијен од информанта С. Д. (26 година, студент, Београд).

9 Примера ради, у породици ауторке овог прилога користи се реч жбојзлица, у значењу саставног дела неког техничког уређаја чији нам тачан назив није

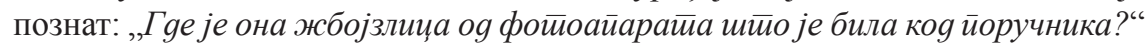
(иоручник је у овом контексту такође фамилијаризам који означава таблу од плуте на којој једни другима остављамо поруке). Ипак, између ова два фамилијаризма ипак постоји јасна творбена разлика: облик йоручник јесте изведеница лексеме йорука и по томе се јасно издваја у односу на произвољност облика жбојзлица.

10 Пример за ово може бити огроман број посведочених назива за справу која служи за убијање инсеката; ауторка овог прилога прикупила је преко 300 таквих примера.

11 У неким лингвистичким традицијама (нпр. германофоној), термин

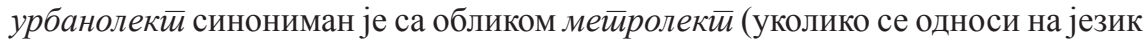
одређеног метрополиса). 
нишком, новосадском урбанолекту или војвођанском, поморавском региолекту (који, дакако, не треба мешати са дијалектаским границама, пошто региолект настаје у просторно повезаним урбаним срединама и може се знатно разликовати од руралног говора, тј. у себе укључивати и елементе из одговарајућег урбанолкта ${ }^{12}$ ). Типичан пример урбанолектно маркиране лексике представљају, рецимо, омине изведене на основу назива градских четврти и других топонима ${ }^{13}$; у Беогарду

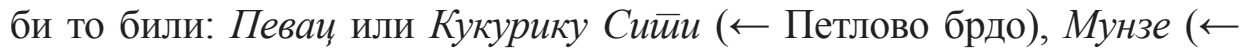
Земун), Ча-ча-ча (збирни облик за насеља на левој обали Дунава

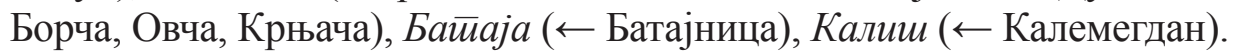

У овакву нестандардну лексику могли би се урачунати и разни

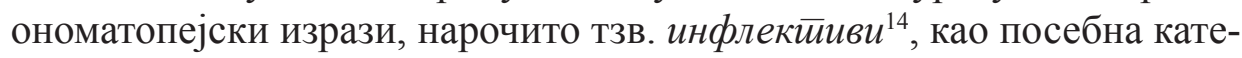
горија узвика, у форми редуковане вербалне форме ономатопејског садржаја, нпр. чеш-чеш, од глагола чешати (се), звижg, од облика звиждати и сл.) Како се у литератури наводи, они настају од глагола који денотирају акустичне феномене из спољне средине (,цикрий“), акустичке невербалне људске активности („цкріуй“"), активности код којих настаје шум (,сещ-сещ “) и активности које немају директне звучне последице (,йривез“), в. Пауер 2013: 273. Нарочито су чести у стриповима, али се бележе и у разговорном стилу.

Коначно, статус нестандардне лексике имају и маркирани елементи присутни у интернетској употреби, нарочито у општењу на форумима, блоговима, социјалним мрежама; на социјалној мрежи фејсбук у овој функцији се најчешће појављују специфични англицизми (које би смо, прецизности ради, могли назвати фејзбукизми$\mathrm{ma}^{15}$ ) чиме се денотирају елементи битни за коришћење саме социјал-

12 Интересантно је да у лингвистичкој литератури на српском језику ови термини нису учестали, могуће и због преовлађујућег интересовања за дијалектологију и отклона нормативиста од разоворног стила, као неке врсте „искварене“ језичке реализације.

13 Наравно, не треба сметнути са ума да велики део омладинског жаргона чине, заправо, елементи урбанолекта; наведени примери само су једна могућа илустрација овог феномена.

14 Термин је устаљен у германистичкој лингвистици од рада В. Тојберта 1998.

15 Хрватски портал www.zargonaut.com дефинише „фејсбукизам“ на следећи начин: pojava ili termin nastao na Facebooku a polagano ulazi u opću uporabu $\therefore \rightarrow$ npr. stavio me NA IGNORE (ne javlja mi se, ne odgovara na poruke, ignorira me lagano... -ne nužno samo na FB:). 
не мреже: „Au!Lajking na kvadrat“, „Idi na kraj mog walla, imas status“ (Дурбаба 2010: 275). Англицизми, и то било адаптирани (у форми позјамљенице), било неадаптирани (употребљени у форми интрафразалног прекључивања кодова, тј. уметањем енглеских речи у исказе) и иначе су чест елемент колоквијалног стила, а срећу се превасходно у омладинском жаргону. Захваљујући присутности енглеског језика у бројним сферама живота младих - и то почев од школског система ${ }^{16}$ преко активности у слободно време (музика, филм, компјутери итд.) па све до употребе енглеског у пословне сврхе - велики проценат млађег становништва активно користи енглески језик (неретко са последицама по употребу матерњег ${ }^{17}$ ). Осим тога, енглески језик као lingua franca ужива статус престижног језика, што такође погодује неселективном и непромишљеном преузимању лексике па чак и одређених синтаксичких структура и читавих фраза ${ }^{18}$. Ови, како их називамо, помодни англицизми последица су уверења да се употребом страних речи и облика показује нарочита ученост, информисаност, образованост ${ }^{19}$.

16 Године 2003. уведена је обавеза учења два страна језика у свим основним школама што је резултовало тиме да се енглески језик сада учи без изузетка у читавој земљи, и то у највећем броју случајева у статусу првог страног језика, с најранијим почетком учења и највећим фондом часова. У средњим стручним школама енглески је такође најчешће једини страни језик који ученици настављају да уче, будући да за њих не важи обавеза учења два језика.

17 Узрока овоме треба тражити и у неодговарајућој настави матерњег језика, тј. њеном протеривању из средњих школа, где програмски садржаји дуги низ година ни не подразумевају бављење српским језиком већ искључиво књижевношћу.

18 Један од примера који све више узима маха јесте коришћење облика $\operatorname{ukag}(a)$ без обавезног глаголског сегмента у постпозицији (трпни глаголски придев), по угледу на енглески: *најбоља рок иесма икаga (the best rock song ever), уместо исправних облика типа икаgа снимљена, икаgа оgсвирана. Такође се често може чути буквалан превод облика earlier this day/week/month = paнuje gанас/ове неgеље/ової месеиа, уместо уобичајених и духу језика примерених конструкција као што су йочеиком gана (јуйрос, ииоком иреиоднева)/ йочеикком неgеље/ йочейком месеца и сл.

19 Ово можемо илустровати примером забележеним у једној радио емисији програма Београд 202 од 11. 08. 2015. Организаторка музичког фестивала у месту Банатски Соколац, најављујући дешавања на три позорнице на којима ће музичари наступати, на питање новинара зашто користи реч стиеји, даје следеће објашњење: „Тако кажемо ако хоћемо gа будемо оиммени и кулиирни.“ Дакле, употреба енглеске речи овде је ствар престижа а не лексичких мањкавости језика који позајмљује. 
Приказ дефиниција нестандардне лексике који смо овде понудили потврђује полазну претпоставку да су значењске границе између појединачних појмова неретко прилично флуидне (нпр. није увек сасвим јасно дефинисано где престаје колоквијализам а почиње жаргон или сленг или шта су разликовни елементи жаргона, аргоа и сленга), због чега и у литератури долази до терминолошких непрецизности и преклапања. Осим тога, одређене нестандардне лексичке јединице могле би се категоризовати на више различитих начина (нпр. истовремено спадати и у жаргонизме и у вулгаризме). Наравно, за потребе истраживања која се баве ширим аспектима усменог општења (нарочито оних социолингвистичких) може бити довољно се елементи разговорног стила једноставно означе као колоквијализми, без прецизнијег терминолошког разликовања. Коначно, може се претпоставити да ће у блиској будућности лингвисти бити све заинтересованији за особености разговорног стила и његов утицај на писану употребу језика, као и за случајеве хибридизације тј. мешања функционалних стилова, због чега ће се наметнути потреба за прецизнијим разграничењем њихових стилогених елемената.

\section{Литература:}

Bugarski, R. (2006). Žargon. Drugo, prerađeno i prošireno izdanje. Beograd: XXI vek.

М. Вујаклија (1992). Лексикон сиираних речи и израза. Четврто допуњено и редиговано издање. Београд: Просвета

Клајн, И. / Шипка, М. (2006). Велики речних стираних речи и израза. Нови Сад: Прометеј.

Милорадовић, С. (2012), Музички жарїон млаgих и молоgежный музыкальный слені̄. Комйарайивни йоїлеg. Београд: Посебна издања Етнографског института САНУ, књига 76.

Pauer, S. (2013). Der Inflektiv - Wortbildungsphänomen mit Zukunft. In: Born, J./Wolfgang

Pöckl (Hrsg.), Wenn die Ränder ins Zentrum drängen“. Berlin: Frank und Timme, 265-286. Речник срйскоїа језика (2007). Нови Сад: Матица српска. 
K. Sornig (1981), Lexical Innovation. A study of slang, colloquialisms and casual speech. Amsterdam: John Benjamin Publishing Company.

Teubert, W. (1998), Neulogie und Prozess. Tübingen: Gunter Narr Verlag.

Tošović B. (1988) Funkcionalni stilovi. Sarajevo: Svjetlost OOUR Zavod za udžbenike i nastavna sredstva [on-line]. Доступно преко: http:// www-gewi.uni-graz.at/gralis-alt/GraLiS_TB/Bibliographie/pdf/ Tosovic_Funkcionalni_stilovi_1988.pdf, pristupljeno avgusta 2015.

Živković, D. (prir.) (1992), Rečnik književnih termina, Drugo, dopunjeno izdanje. Beograd:

Olivera Durbaba

\section{Zusammenfassung}

\section{ZUR UNSTANDARDISIERTEN LEXIK IN LEXIKOGRAPHISCHEN QUELLEN}

im vorliegenden Artikel werden Ergebnisse einer Analyse der Begriffsbestimmungen dargelegt, die sich in einigen der umfangreichsten und zuverlässigsten Standard- und Fachwörterbücher der serbischen Sprache auf umgangssprachliche und weitere nichtstandardsprachliche lexikalische Einheiten beziehen (etwa Kolloquialismen, Jargon, Argot, Slang, Vulgarismen, Internet-Anglizismen und andere stilogene Sprachmittel, insbesondere diejenigen, die zur Intensivierung des Ausdrucks benutzt werden). Durch unser explorativ-analytisches Verfahren wurde festgestellt, dass diese Begriffe in den untersuchten Quellen weder terminologisch einheitlich noch gegenseitig differenziert definiert werden. In weiteren linguistischen Studien sollten daher präzisere Bestimmungen nichtstandardsprachlicher Elemente erstrebt werden. 


\section{ПРИЛОГ 1:}

Утврђујући актуелност тј. застарелост жаргонског значења лексеме банка обавила сам интервјуе с групом млађих информаната $($ н $=7)$, студената основних и мастер студија различитих области, који су посведочили да овај израз не користе активно; већина информаната је и у рецептивном смислу показала неупућеност у значење (један сматрајући нпр. да банка представља 1000 динара), док је двоје рекло да им је облик познат у значењу „десет година“ (старости). Остали су навели да је у питању израз који користе (или су користили) старији људи.

У неформалном интернетском речнику сленга www.vukajlija. com забележена су следећа значења ове лексеме (у напоменама 22 и 23 наведени су и неки примери употребе):

(1) апоен од 10 јединица одређене валуте: najcesce se odnosi stranu valutu, tj evro: "Juce sam slupo 5 banki u kladzi". У значењу апоена наводе се још и изрази konj,cigla,som....

(2) безначајан новац, нарочито у колокацији жушиа банка: Veleprodajna cena pišljivog boba.

(3) деценија, период од 10 година, најчешће означава 10 година живота неког лица ${ }^{20}$ : Opaaaa, danas puniš 5 banki! $h^{21}$

(4) ознака за брзину у шоферском сленгу: Jedna banka $=10 \mathrm{~km} /$

20 A: Kakva ti je ono bakaner što je vodaš?

B: Ma ništa ozbiljno, što bi se reklo učiteljica!

A: Koliko nosi na ledjima?

B: Četiri banke, najbolje doba!

A: Što jes', jest!

21 - Kolega, po rasporedu vozimo zajedno do Zaječara...koliko brzo ovaj tvoj ide?

- Osam i po, devet banke maksimalno, i to nizbdo! 